\title{
原著
}

\section{喫煙者に抢ける歯周治療期間中の付着の衰失と 臨床的パラメータとの関連について}

\author{
関 野 愉*1,2 \\ 沼部幸博 $* 1$ \\ 鈴木史彦*2 \\ 宮尾益佳*2 \\ 築 舘勇 樹*2 \\ 今村恭也 $* 2$ \\ 中山大輔*2 \\ 岡本 浩*3 \\ ${ }^{* 1}$ 日本歯科大学生命歯学部 歯周病学講座 \\ *2奥羽大学歯学部歯科保存学第一講座歯周病学教室 \\ *3 奥羽大学歯学部附属病院
}

中嶋大誠 $* 2$

池田祥恵*2

（受付日：2007 年 6 月 12 日 受理日：2007 年 8 月 3 日)

\section{Relationship Between Probing Attachment Loss and Clinical Parameters During Periodontal Therapy in Smoking Patients}

\author{
Satoshi Sekino*1,2, Yukihiro Numabe*1, Fumihiko Suzuki*2, Taisei Nakajima*2, \\ Masuyoshi Miyao*2, Yuki Tsukidate*2, Yasunari Imamura*2, Sachie Ikeda*2, \\ Daisuke Nakayama*2, and Hiroshi Okamoto*3 \\ ${ }^{* 1}$ The Nippon Dental University, Department of Periodontology, School of Life Dentistry \\ at Tokyo, Tokyo, Japan, \\ *2 Ohu University, Department of Periodontics, Faculty of Dentistry, Fukushima, Japan, \\ ${ }^{*}$ Ohu University, Dental Hospital, Faculty of Dentistry, Fukushima \\ (Received : June 12, 2007 Accepted : August 3, 2007)
}

\begin{abstract}
The relationship between various clinical parameters and probing attachment loss during periodontal therapy was retrospectively evaluated in habitual smokers. Twelve habitual smokers (smoking group : 1 woman, 11 men; mean age $54.5 \pm 12.4$ years) and 12 non-smokers (non-smoking group : 3 women and 9 men; mean age, $54.4 \pm 9.8$ years) who had received active periodontal therapy and maintenance care for at least 2 years at the dental hospital of Ohu University were enrolled. All subjects were clinically examined at baseline for the number of missing teeth (MT), probing pocket depths (PPD), clinical attachment levels (CAL), bleeding on probing scores (BOP), and plaque scores (PCR). Following the examination, all the patients received oral hygiene instructions and cause-related periodontal therapy. After treatment, all the subjects were followed up at regular intervals of 1 to 3 months. A re-examination, including an assessment of the same

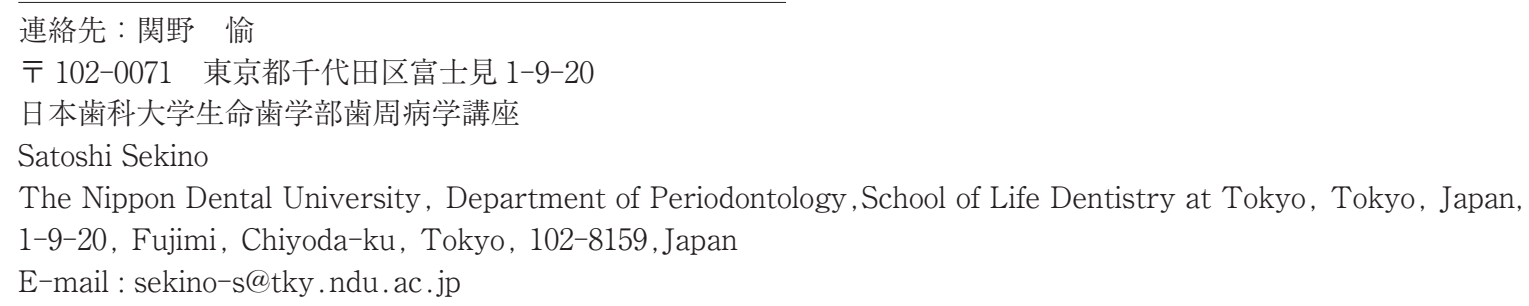


parameters as those studied at baseline, was performed after 2 years. The clinical parameters during the treatment period were investigated for their association with the percentage of sites with a probing attachment loss $\geqq 2 \mathrm{~mm}$ over the 2 -year period for each group of patients. The data were evaluated using the Spearman rank correlation. In the smoking group, little or weak relationships were observed for all clinical parameters. On the other hand, the number of missing teeth at re-examination, the percentage of sites with a CAL $\geqq 5 \mathrm{~mm}$ at baseline and at re-examination and/or the percentage of sites with a PPD $\geqq 6 \mathrm{~mm}$ at re-examination were significantly correlated with probing attachment loss in the non-smoking group. Thus, smoking may make Prediction of prognosis of periodontal therapy more difficult, and strict periodontal evaluations are necessary for habitual smokers.

Nihon Shishubyo Gakkai Kaishi (J Jpn Periodontol) 49 : 215 - 223, 2007.

Key words : probing attachment loss, dental plaque, probing pocket depth, clinical attachment level, bleeding on probing

要旨：本後乃向き研究の目的は喫煙者に扔ける種々の臨床的パラメー夕と歯周治療期間中の付着の衰失との関 連を評価することである。奥羽大学歯学部附属病院にて, 動的歯周治療とメインテナンス治療を 2 年以上受診し た喫煙者 (喫煙群：男性 11 名,女性 1 名, 平均年齢 $54.5 \pm 12.4$ 歳) と非喫煙者(非喫煙群：男性 9 名, 女性 3 名, 平均年齢 $54.4 \pm 9.8$ 歳) からそれぞれ 12 名のデータを抽出し分析を行った。ベースライン (BL) 診査時に, すべ ての被験者の衰失歯 (MT) 数, プロービングポケットデプス, (PPD), 臨床的アタッチメントレベル (CAL), プロー ビン時の出血 $(\mathrm{BOP})$ ，プラークスコア $(\mathrm{PCR})$ を記録した。診査の後, 全ての被験者に対し, 口腔衛生指導および 原因除去治療を行い，それらの治療終了後，1～3 カ月の間隔で，リコールプログラムに組み入れた。BL 診査か ら平均約 2 年後に同様の臨床的パラメータについて再評価を行った。各群の観察期間中の臨床パラメータと 2 年 間で $2 \mathrm{~mm}$ 以上付着の培失が起こった部位の頻度 $(\%)$ との相関を Spearmanの順位相関により解析した。喫煙群 においては, 全ての臨床的パラメータは弱い相関しか認められなかった。他方, 非喫煙群においては, 全歯面の 分析では, 再評価時の MT 数㧍よび $\mathrm{CAL} \geqq 5 \mathrm{~mm}$ の頻度(\%)が, BL 時 PPD $\geqq 4 \mathrm{~mm}$ の部位の分析では再評価時 の $\mathrm{PPD} \geqq 6 \mathrm{~mm}$ の頻度 $(\%)$ および $\mathrm{BL}$ 時と再評価時の $\mathrm{CAL} \geqq 5 \mathrm{~mm}$ の頻度 (\%)が付着变失部位の頻度と有意に 相関した。したがって, 喫煙患者では, 歯周治療の予後予測が困難になるので, より厳密な診査が必要であると 考えられた。

キーワード：付着の䚻失, プラーク，プロービングポケットデプス, 臨床的アタッチメントレベル, プロービ ング時の出血

\section{緒言}

歯周治療を遂行していく上でその中核となるのは, 歯肉縁上プラークコントロールと歯肉縁下のインスッ ルメンテーションであり, これらの有効性は多数の臨 床研究により報告されてきた1)。しかし,治療の結果, 全ての患者または歯面が同様に治癒するわけではな く，部位によっては付着の䚻失が起こる場合もあるこ とが報告されている2-3)。

歯周病の臨床に执いて，プラークスコア，プロービ ングデプス，プロービング時の出血などの診査が日常 的に行われており，これらの診查結果と歯周治療期間 中に生ずる付着の堮失との関連について様々な報告が なされている ${ }^{4-9)}$ 。繰り返しの歯肉縁下のインスッル メンテーションを伴うメインテナンス期間における観
察研究で,Claffey と Egelberg $(1995)^{8)}$ は, 患者単位 の分析を行い，42ヶ月の観察期間中に生じた付着の噩 失の頻度と, 歯周ポケットが $6 \mathrm{~mm}$ 以上の部位の頻度 との間に有意な相関があることを示した。また, Joss ら $(1994)^{7)}$ は同様の 53ケ月間の観察研究において, ブリーディングスコアと付着の衰失が生じた部位数と の間に中等度の相関がある事を報告している。また， Badersten ら (1985b) ${ }^{2}$ ) は, 非外科的治療期間中の付 着の垴失を部位単位で分析した研究で, プラーク，プ ロービング時の出血および排膿がみられた回数と残存 した歯周ポケットの沿さは付着の衰失と関連している が, それらのパラメータの感度と陽性的中率は低いこ とを報告し, 患者単位の研究9)では, 治療前に深い歯周 ポケットを多く有していた患者は付着の衰失が少ない ことを報告している。このように，プロービングによ り得られる臨床的デー夕は, 歯周治療期間中の付着の 
喪失を予測するのに完全なものとはいえないまでも， ある程度は有効であると考えられる。

喫煙者の場合, これらの歯周病学的パラメータが非 喫煙者と異なった数值を示す研究結果が報告されてい $る^{10-12)}$ 。Biddle ら (2001) ${ }^{10)}$ は, 喫煙者の歯肉は, 非喫 煙者と比較してプロービングの值が低く記録される可 能性を示した。また，喫煙者のほうが非喫煙者よりも 歯肉出血が起こりにくい事が報告されている ${ }^{11-12)}$ 。 これらの事から，喫煙者の場合は，プロービングによ る歯周病の診査結果が過小評価され, 予後の予測がよ り困難になる可能性が考えられる。しかし喫煙と臨床 的パラメー夕に関する研究報告の多くは断面的な調査 であり，それが経時的に付着の衰失にどう関わるかを 分析した報告はない。

今回, 我々は喫煙者に扔ける歯周炎に関連する各臨 床的パラメータと歯周治療期間中の付着の衰失との関 連を後ろ向きに解析し，喫煙が治療の予後予測にどの ように影響を与えるかを，非喫煙者の場合と比較する ことにより検討した。

\section{被験者と方法}

\section{1. 被験者}

奥羽大学歯学部附属病院を 1991 年から 2002 年まで の間に受診し，その後約 2 年間以上，動的歯周治療と メインテナンス治療を受診している喫煙者(喫煙群：1 日に 10 本以上喫煙, 男性 11 名,女性 1 名, 平均年齢 $54.5 \pm 12.4$ 歳) と非喫煙者 (非喫煙群: 男性 9 名, 女 性 3 名, 平均年齢 $54.4 \pm 9.8$ 歳) からそれぞれ 12 名 のデー夕を抽出し分析を行った。なお，本研究は奥羽 大学附属病院倫理委員会にて承認を得, 患者資料につ いては連結不可能な匿名化を行い使用した。対象者 は, 初診時に歯周ポケットの深さ $5 \mathrm{~mm}$ 以上でプロー ビング時の出血を示す部位を有し, 治療開始前の6ケ 月間抗生物質を服用しなかった者とした。

\section{2. 診査項目}

臨床的パラメー夕は, 術者間抢よび術者内の再現性 が確認された 3 人の術者により計測された。衰失歯 数, 修復物の状況など一般的歯科診査に加え, 以下の 診査を行った。

1)プラーク付着状況 (PCR)

エリスロシン溶液(ロンデル・レッド®，サンデンタ ル, 大阪)にて歯面を染め出した後, プラーク付着の有 無を記録し,プラーク付着部位の割合 (\%)を算出した。

2)プロービングポケットデプス (PPD)

手用歯周プローブ

(HO プローブ®，マイクロテック，東京)を用いて，歯
肉辺縁からの距離を $1 \mathrm{~mm}$ 単位で測定した。

3) 臨床的アタッチメントレベル (CAL)

セメントーエナメル境 $(\mathrm{CEJ})$ あるいは補綴物の辺縁 部から臨床的ポケット底までの距離を $1 \mathrm{~mm}$ 単位で測 定した。

4) プロービング時の出血 (BOP)

PPD 測定後に生じた出血の有無を肉眼にて評価し, 出血部位の割合 $(\%)$ を算出した。

ベースライン $(\mathrm{BL})$ 抢よび再評価時 $(\mathrm{BL}$ から平均 $1.9 \pm 0.2$ 年後)に, 上記の臨床的パラメータを, 第三 大臼歯を除く全ての歯の近心煩側, 煩側中央, 遠心煩 側, 近心舌側, 舌側中央, 遠心舌側の 6 点について評 価した。

\section{3. 歯周治療}

BL 診査の後, 全ての被験者に動機づけ, 口腔清掃 指導を行い, その後, BOPがみられた部位にのみ, 非 外科的に歯肉縁下のインスツルメンテーションを行っ た。積極的治療終了後, 各被験者はそれぞれの必要に 応じて, 1〜3ヶ月に一度のメインテナンスプログラ ムに組み入れた。メインテナンスにおいては, 動機付 け, 口腔衛生指導, 専門家による歯面清掃 (PTC)を 行った。

\section{4. 付着喪失部位の判定}

観察期間中に CAL が $2 \mathrm{~mm}$ 以上増加した部位を付 着衰失部位とした ${ }^{4-6)}$ 。

\section{5. 統計学的解析}

BL 時および再評価時の各臨床的パラメータの喫煙 群または非喫煙群における2 群間の比較にはStudent の $\mathrm{t}$ 検定または Mann-WhitneyのU 検定を用いた。 $\mathrm{BL}$ 時掞よび再評価時の喪失歯数, 全歯面に扔けるプ ラークの付着頻度 (\%), PPD が $6 \mathrm{~mm}$ 以上の部位の頻 度(\%), CAL が $5 \mathrm{~mm}$ 以上の部位の頻度 (\%), BOP の 頻度 (\%) と付着变失部位の頻度 (\%) との相関を, Spearmanの相関係数を用いて検定を行い, 危険率 5\% 以内を統計学的に有意な相関とした。また, BL 診査 で PPD が $4 \mathrm{~mm}$ 以上と記録された部位についても同 様の算出抢よび検定を行った。なお，歯周治療期間中 に抜歯した歯は解析から除外した。

\section{結＼cjkstart果}

\section{1. 全歯面}

喫煙群㧍よび非喫煙群の BL 時㧍よび再評価時の各 臨床的パラメータの平均值と標準偏差を表 1,2 に示 す。全てのパラメータについて群間で統計学的有意差 はみられなかった。

各臨床的パラメー夕と付着の喪失部位の頻度の相関 
表 $1 \mathrm{BL}$ 時の両群の人口統計学的データおよび臨床的パラメータ

\begin{tabular}{lccc}
\hline & 喫煙群 & 非喫煙群 & 両群の比較検定 \\
\hline 年齢 & $54.5 \pm 12.4$ & $54.4 \pm 9.8$ & $\mathrm{NS}$ \\
男/女 & $11 \mathrm{VS} 1$ & $9 \mathrm{VS} 3$ & $\mathrm{NS}$ \\
䨤失曾数 & $4.3 \pm 5.9$ & $2.3 \pm 3.9$ & $\mathrm{NS}$ \\
平均 BOP(\%) & $31.2 \pm 21.6$ & $29.7 \pm 23.1$ & $\mathrm{NS}$ \\
平均 PPD (mm) & $3.2 \pm 0.9$ & $2.8 \pm 0.8$ & $\mathrm{NS}$ \\
平均 CAL (mm) & $3.9 \pm 1.3$ & $3.4 \pm 1.3$ & $\mathrm{NS}$ \\
平均 $\geq 6 \mathrm{~mm} \mathrm{PPD} \mathrm{( \% )}$ & $12.8 \pm 13.4$ & $11.5 \pm 17.0$ & $\mathrm{NS}$ \\
平均 $\geq 5 \mathrm{~mm}$ CAL (\%) & $32.1 \pm 25.7$ & $25.7 \pm .26 .6$ & $\mathrm{NS}$ \\
\hline
\end{tabular}

NS 統計学的有意差なし

表 2 再評価時の両群の臨床的パラメータ

\begin{tabular}{lccc}
\hline & 哭煙群 & 非喫煙群 & 両群の比較検定 \\
\hline 䨤失齿数 & $5.7 \pm 6.6$ & $3.2 \pm 4.3$ & $\mathrm{NS}$ \\
平均 PCR $(\%)$ & $20.0 \pm 13.4$ & $20.8 \pm 19.1$ & $\mathrm{NS}$ \\
平均 BOP(\%) & $7.2 \pm 11.6$ & $3.1 \pm 4.1$ & $\mathrm{NS}$ \\
平均 PPD (mm) & $2.2 \pm 0.3$ & $2.1 \pm 0.3$ & $\mathrm{NS}$ \\
平均 CAL(mm) & $3.2 \pm 0.8$ & $3.0 \pm 1.0$ & $\mathrm{NS}$ \\
平均 $\geq 6 \mathrm{~mm}$ PPD (\%) & $0.3 \pm 0.6$ & $0.7 \pm 1.6$ & $\mathrm{NS}$ \\
平均 $\geq 5 \mathrm{~mm}$ CAL (\%) & $23.5 \pm 14.7$ & $27.5 \pm 29.1$ & $\mathrm{NS}$ \\
平均 $\geq 2 \mathrm{~mm}$ A.Loss (\%) & $6.5 \pm 7.1$ & $5.5 \pm 4.5$ & $\mathrm{NS}$ \\
\hline
\end{tabular}

NS 統計学的有意差なし

表 3 両群の各臨床的パラメータと付着の衰失が起こった部位の頻度 (\%)との相関係数

\begin{tabular}{lcc}
\hline & 喫煙群 & 非喫煙群 \\
\hline BL時の亜失歯数 & 0.11 & 0.40 \\
再評価時の欠損歯数 & 0.05 & $0.58 *$ \\
再評価時のPCR(\%) & -0.10 & 0.05 \\
BL時の BOP (\%) & -0.27 & 0.10 \\
再評価時の BOP (\%) & -0.14 & 0.44 \\
BL時の PPD6mm以上の部位 (\%) & -0.06 & 0.21 \\
再評価時のPPD6mm 以上の部位(\%) & 0.29 & 0.01 \\
BL時のCAL5mm 以上の部位(\%) & 0.00 & 0.29 \\
再評価時のCAL5mm以上の部位(\%) & -0.19 & $0.66 *$ \\
\hline * 統計学的に有意な相関あり $(p<0.05)$ & & \\
BL=ベースライン & &
\end{tabular}

係数を表 3 に示す。喫煙群において，付着の衰失部位 の頻度と有意に相関する臨床的パラメー夕はなかった が，非喫煙群においては，再評価時の衰失歯数(図 1)
および CAL5mm 以上の部位の頻度 (図 2)が有意な相 関を示した。 


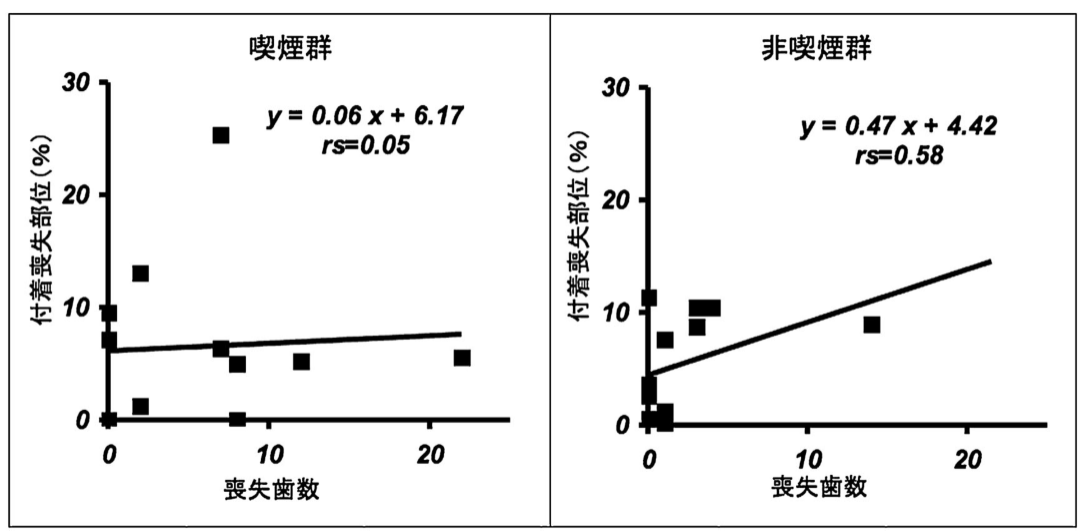

図 1 再評価時の喪失歯数と付着喪失部位 $(\%)$ との相関図

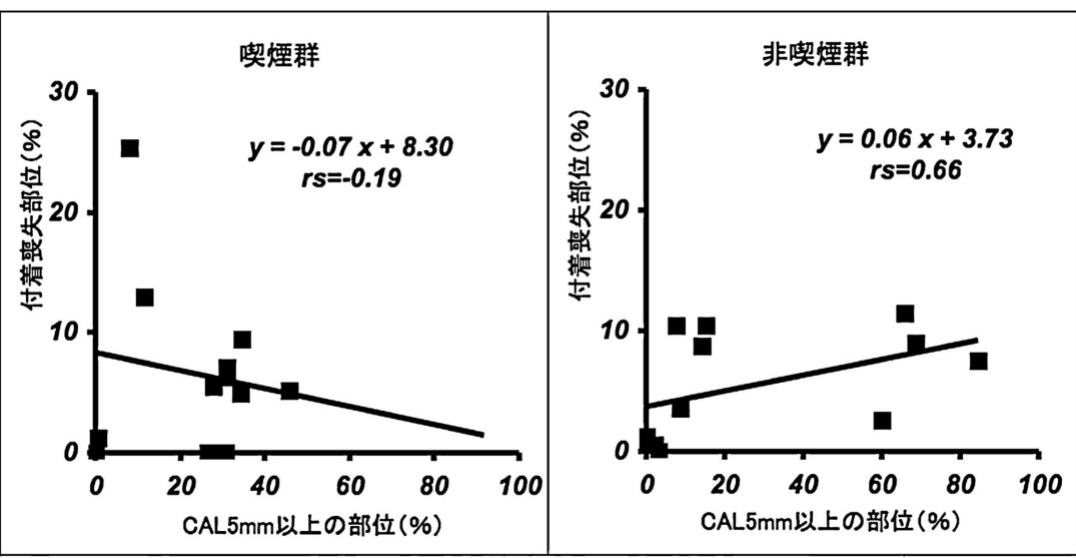

図 2 再評価時の CAL5mm 以上の部位 $(\%)$ と付着哀失部位 $(\%)$ との相関図

表 $4 \mathrm{BL}$ 時 $\mathrm{PPD} 4 \mathrm{~mm} \leqq の$ 部位における $\mathrm{BL}$ 時の両群の臨床的パラメータ

\begin{tabular}{lccc}
\hline & 喫煙群 & 非喫煙群 & 両群の比較検定 \\
\hline 平均 BOP(\%) & $68.9 \pm 31.6$ & $86.8 \pm 14.4$ & $\mathrm{NS}$ \\
平均 PPD (mm) & $5.1 \pm 0.7$ & $4.7 \pm 0.4$ & $\mathrm{NS}$ \\
平均 CAL (mm) & $5.5 \pm 1.3$ & $5.2 \pm 1.0$ & $\mathrm{NS}$ \\
平均 $\geq 6 \mathrm{~mm}$ PPD (\%) & $19.8 \pm 20.3$ & $15.2 \pm 21.7$ & $\mathrm{NS}$ \\
平均 $\geq 5 \mathrm{~mm} \mathrm{CAL} \mathrm{( \% )}$ & $61.4 \pm 30.5$ & $60.5 \pm 27.0$ & $\mathrm{NS}$ \\
\hline
\end{tabular}

NS 統計学的有意差なし

\section{2. $\mathrm{PPD} 4 \mathrm{~mm}$ 以上の歯面}

喫煙群および非喫煙群の BL 時および再評価時の各 臨床的パラメータの平均值と標準偏差を表 4,5 に示 す。全てのパラメータについて群間で統計学的有意差 はみられなかった。

各臨床的パラメータと付着喪失部位の頻度の相関係 数を表 6 に示す。契煙群では臨床的パラメータと付着
喪失部位の頻度との有意な相関はみられなかった。他 方, 非契煙群においては, BL 時と再評価時の CAL5mm 以上の部位の頻度 (図 3,4), および再評価 時の PPD6mm 以上の部位の頻度 (困 5)が付着弈失部 位の頻度に有意な相関を示した。 
表 $5 \mathrm{BL}$ 時 PPD4mm @の部位における再評価時の両群の臨床的パラメータ

\begin{tabular}{lccc}
\hline & 喫煙群 & 非喫煙群 & 両群の比較検定 \\
\hline 平均 BOP(\%) & $5.2 \pm 6.4$ & $14.8 \pm 12.3$ & NS \\
平均 PPD (mm) & $2.7 \pm 0.6$ & $2.6 \pm 0.3$ & NS \\
平均 CAL(mm) & $4.1 \pm 1.0$ & $3.5 \pm 1.1$ & NS \\
平均 $\geq 6 \mathrm{~mm} \mathrm{PPD} \mathrm{( \% )}$ & $1.1 \pm 1.6$ & $1.4 \pm 3.5$ & $\mathrm{NS}$ \\
平均 $\geq 5 \mathrm{~mm}$ CAL (\%) & $39.1 \pm 20.0$ & $29.9 \pm 26.3$ & $\mathrm{NS}$ \\
平均 $\geq 2 \mathrm{~mm}$ Attachmet Loss (\%) & $3.0 \pm 5.8$ & $1.9 \pm 3.8$ & $\mathrm{NS}$ \\
\hline
\end{tabular}

NS 統計学的有意差な

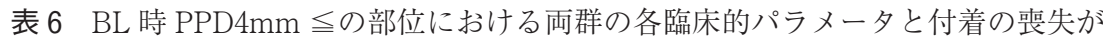
起こった部位の頻度 $(\%)$ との相関係数

\begin{tabular}{lcc}
\hline & 喫煙群 & 非喫煙群 \\
\hline BL時の BOP (\%) & 0.00 & 0.40 \\
再評価時の BOP (\%) & 0.08 & 0.14 \\
BL時の PPD6mm以上の部位 $(\%)$ & -0.37 & 0.33 \\
再評価時の PPD6mm以上の部位 (\%) & -0.20 & $0.62 *$ \\
BL時のCAL5mm 以上の部位 $(\%)$ & -0.24 & $0.62 *$ \\
再評価時のCAL5mm以上の部位 $(\%)$ & 0.03 & $0.58 *$ \\
\hline
\end{tabular}

* 統計学的に有意な相関あり $(p<0.05)$

$\mathrm{BL}=$ ベースライン

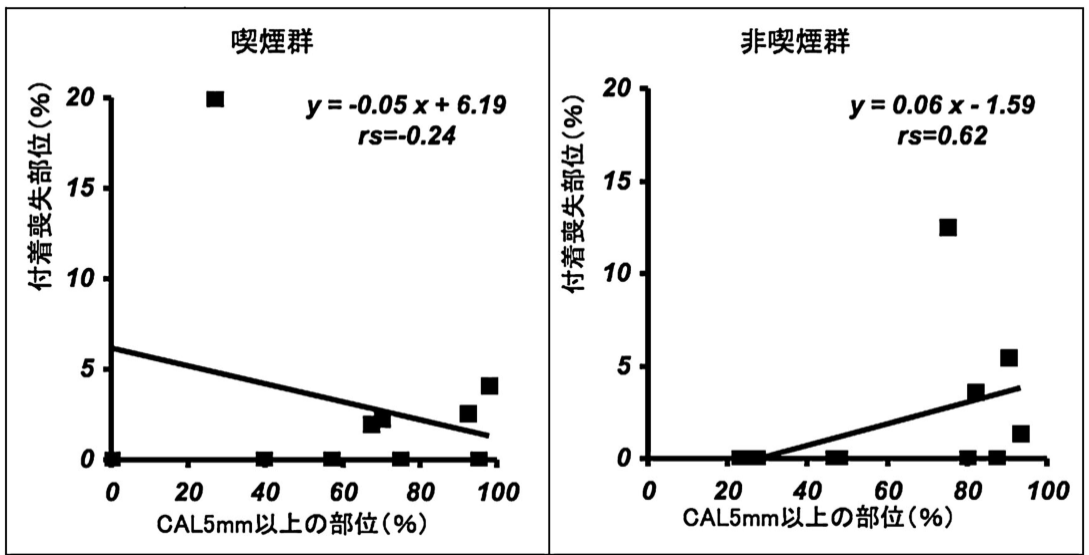

図 $3 \mathrm{PPD} 4 \mathrm{~mm}$ 以上の部位における付着哀失部位(\%)と BL 時の CAL $5 \mathrm{~mm}$ 以上の部位 $(\%)$ の相関図

考察

本研究では，全歯面の分析に加えて，BL 時にPPD が $4 \mathrm{~mm}$ 以上あった部位に限定した分析を行った。そ の理由は, $3 \mathrm{~mm}$ 以下の浅い歯周ポケットの場合, 歯肉
縁下のインスツルメンテーションによる外傷によって 付着の喪失が起こると考えられるからである13)。そ の結果，全歯面の分析では付着弈失部位との間に有意 な相関がみられなかったいくつかのパラメータに有意 な相関がみられた。全歯面に対する分析では，非契煙 者における付着喪失部位の割合と, 再評価時の欠損歯 


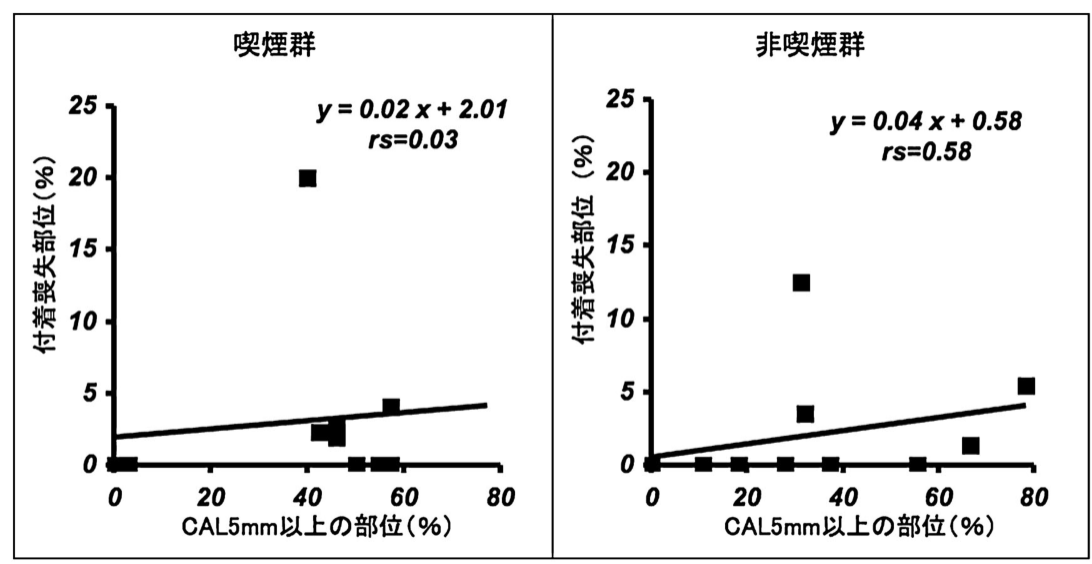

図 $4 \mathrm{PPD} 4 \mathrm{~mm}$ 以上の部位における付着喪失部位(\%)と再評価時の CAL5mm 以上の部位 $(\%)$ の相関図

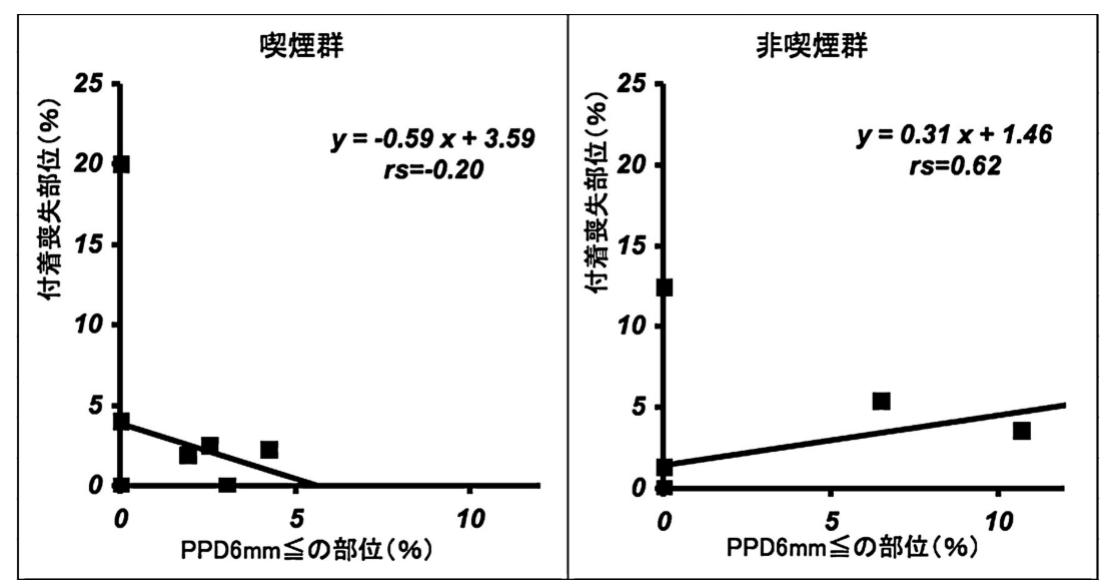

図 $5 \mathrm{PPD} 4 \mathrm{~mm}$ 以上の部位における付着衰失部位(\%)と再評価時の PPD $6 \mathrm{~mm}$ 以上の部位 $(\%) の$ 相関図

数およびCAL5mm 以上の部位との間にのみ有意な 相関がみられたが, PPD $4 \mathrm{~mm}$ 以上の部位に対する分 析の結果, BL 時と再評価時の CAL5mm 以上の部位 および再評価時の PPD6mm 以上の部位の割合とも有 意な相関が得られた。

噩失歯数およびアタッチメントロスを起こしている 部位が多いという事は，それだけ歯周病が重篤である 事を示している。すなわち被験者の歯周病に対する感 受性の高さを表しているものと考えられる。したがっ て非喫煙群においてこれらの指標が付着の喪失と相関 したという結果は，歯周治療期間中に生じた付着の喪 失が，歯周病に対する感受性に関係している可能性を 示唆している。しかしながら, 再評価時の PCR の值 が喫煙群と非契煙群で差がなかったにもかかわらず, 喫煙群では非喫煙群にみられたような有意な正の相関
がみられなかった。これは図 1,2 にみられるように， 喫煙者において衰失歯数やアタッチメントロスの頻度 が比較的少ないにも関わらず付着喪失部位が多い被験 者が存在する事に一部起因すると考えられる。多くの 疫学研究では, 契煙者の方が非契煙者よりも歯周病が 重篤である事が示され, さらに禁煙した患者では喫煙 者よりも歯周病罹患頻度が低いことが報告されてい る14)。これは, 契煙によって宿主が本来備えている歯 周病に対する感受性が変わってしまう可能性を示唆し たものであり，本研究において比較的歯周病が軽度 だった契煙者で付着喪失が多く起こったのもこの理由 によるものと思われる。

非喫煙群において，深い歯周ポケットの頻度が付着 喪失の頻度と相関したという結果は, Claffeyと Egelberg $(1995)^{8)}$ の長期研究結果と一致している。し 
かし喫煙群においてはこのような有意な相関がみられ なかった。Biddleら (2001) ${ }^{10)}$ は，大臼歯を対象とした 研究で, $4 \mathrm{~mm}$ 以上の歯周ポケットにプロービングし た場合，非喫煙者では喫煙者よりもプローブの先端が より深く組織内に入り込むことを観察した。その理由 として, 喫煙者では非喫煙者よりも歯石形成量が多く, 炎症の程度が低く，軟組織が薄い事をあげている。し たがって本研究において $4 \mathrm{~mm}$ 以上の $\mathrm{PPD}$ を対象と した分析で喫煙者において深いPPDの頻度と付着喪 失の頻度に相関がみられなかったのは, 歯周病の程度 が非喫煙者の場合よりも過小評価された事に起因する 可能性が考えられる。

本研究では再評価時の PCR は付着の亦失に相関し なかった。これらの結果は他の患者単位での分析を含 む研究報告と一致している ${ }^{8)}$ 。積極的歯周治療後の自 己および専門家による歯面清掃を含むプラークコント ロールは歯周病の予後を左右する重要な要因であ る15-17) が, 本研究においてはほとんどの被験者のコン プライアンスが高く， 口腔衛生の状態も良好であった ことが，付着喪失と相関しなかった理由であると思わ れる。

被験者単位の分析で，BOP が付着喪失と相関しな かったという結果は, 他の研究結果と一致している ${ }^{8)}$ 。 しかし, 部位単位で分析が行われた研究結果では, BOP がない部位は付着の哀失が起こる確率が低い, すなわち陰性的中率が高いことが報告されている4）。 契煙者の場合は非喫煙者と比較して歯肉からの出血が 少ないといわれ，また禁煙をすることにより出血が多 くなることも報告されている18-19) ので，上記の陰性 的中率が非契煙者よりも低くなる可能性がある。

本研究では，プローブによる計測で観察期間中にア タッチメントレベルの值が $2 \mathrm{~mm}$ 以上増加した部位を 付着の喪失部位と定義した。しかしながら，上述のよ うに喫煙者と非契煙者では軟組織のプロービングに対 する抵抗性が異なるので，この基準が適切なものか一 考の余地がある。前述の Biddleら (2001) ${ }^{10)}$ の研究で は，喫煙者では非喫煙者よりもプローブの軟組織内の 到達性が低く，その差はポケットが深い場合により大 きくなる事が報告されている。したがって，臨床的に 同程度の付着の衰失がみられたとしても，実際の結合 組織性付着の最歯冠側部の位置は，喫煙者の場合には 非喫煙者と比較してより根尖側に位置している事が考 えられる。今後, 組織学的な観察やエックス線所見な どにより詳細に検討すべき課題である。

Bardersten ら (1985b, 1985c) 2),20) は歯周ポケット における歯周治療に伴う付着の衰失の原因について, 浅い歯周ポケットの場合には治療に伴う外傷が関わっ
ていると記述している。また, $4 \mathrm{~mm}$ 以上の歯周ポケッ 卜の場合でも，付着の衰失が起こった部位の多くに， 出血や排膿がみられず，治療後に残ったポケットも深 くなかった事から, 臨床的に観察可能な炎症反応を作 り出さない細菌学的因子やその他の因子が付着の变失 に関わっている可能性がある事を述べている。しかし ながら、これらの研究では，被験者に喫煙者が含まれ ている可能性があり，解釈に注意が必要である。

本研究では喫煙者を自己申告により同定した。しか し, この方法は, digit bias, 煙を吸い込む量の違い, 受 動喫煙の有無が不明，喫煙本数を過大評価または過小 評価しやすいなどの事から，必ずしも正確な方法では ない。呼気中の一酸化炭素濃度や唾液中のコチニン 量 ${ }^{21)}$ な゙゙,より客観的な方法を用いた分析が推奨され ている。また, Jetteら (1993) ${ }^{22)}$ は，高齢者を対象と した研究で，喫煙年数が歯周病の重篤度に影響するこ とを報告している。しかしながら，本研究は後ろ向き 研究であり，これらの情報を得る事ができなかった。

今後は，より大人数による長期的な前向き研究によ る分析が必要である。また，被験者単位の分析のみな らず部位単位の分析により新たな知見が得られる可能 性もあるだろう。臨床においては，とくに契煙患者の 場合には，歯周治療に対する反応が悪い部位や再発が 起こった部位の診断を行う際，プロービングにより得 られた結果をより厳密に分析する事が必要である。さ らに歯肉溝滲出液からの化学物質や細菌学的な手法に よる補足的な診査の有効性についても検討の余地があ ろう。

\section{文献}

1) Lindhe, J., Karring, T., Lang N. P, : 岡本浩(監 訳) : Lindhe 臨床歯周病学とインプラント 第 4 版, クインテッセンス出版 473-490, 2005.

2) Badersten A, Nilveus R, Egelberg, J. Effect of nonsurgical periodontal therapy. VII. Bleeding, suppression and probing depth in sites with probing attachment loss . J Clin Periodontol, 12 : 432-440, 1985 .

3) Westfelt E, Rylander H, Dahlen G, Lindhe J. The effect of supragingival plaque control on the progression of advanced periodontal disease. J Clin Periodontol 25 : 536-541. 1998

4) Lang N P, Joss A, Orsanic T, Gusberti F A, Siegrist B E : Bleeding on probing. A predictor for the progression of periodontal disease?J Clin Periodontol, $13:$ 590-596, 1986.

5) Lang N P, Adler R, Joss A, Nyman S : Absence of 
bleeding on probing. An indicator of periodontal stability. J Clin Periodontol, 17 : 714-721, 1990.

6) Kaldahl W B, Kalkwarf K L, Patil K D, Molvar M P. Relationship of gingival bleeding, gingival suppuration, and supragingival plaque to attachment loss. J Clin Periodontol, 61 : 347-351, 1990.

7) Joss A, Adler R, Lang, NP. Bleeding on probing. A parameter for monitoring periodontal conditions in clinical practice. J Clin Periodontol, 21 : 402-408, 1994.

8) Claffey N, Egelberg J. Clinical indicators of probing attachment loss following initial periodontal treatment in advanced periodontitis patients. J Clin Periodontol, 22:690-696, 1995.

9) Badersten A, Nilveus R, Egelberg, J. Effect of nonsurgical periodontal therapy. VIII. Probing attachment changes related to clinical characteristics . J Clin Periodontol, 14 : 425-432, 1987.

10) Biddle A J, Palmer R M, Wilson R F, Watts T L. Comparison of the validity of periodontal probing measurements in smokers and non-smokers. J Clin Periodontol, $28:$ 806-812, 2001.

11) Bergström J, Floderus-Myrhed B. Co-twin control study of the relationship between smoking and some periodontal disease factors. Community Dent Oral Epidemiol, 11 : 113-116, 1083.

12) Preber H, Bergström J. Occurrence of gingival bleeding in smoker and non-smoker patients. Acta Odontol Scand, $43:$ 315-320, 1985

13) Badersten A, Nilveus R, Egelberg, J. Effect of nonsurgical periodontal therapy. II. Severely advanced periodontitis. J Clin Periodontol, 11 : 63-76, 1984a.
14) Bergström J. Tobacco smoking and chronic destructive periodontal disease. Review. Odontology, $92: 1-8,2004$.

15) Cercek J F, Kiger R D, Garrett S, Egelberg J. Relative effects of plaque control and instrumentation on the clinical parameters of human periodontal disease. J Clin Periodontol, 10 : 46-56, 1983.

16) Magnusson I, Lindhe J, Yoneyama T, Liljenberg B. Recolonization of a subgingival microbiota following scaling in deep pockets. J Clin Periodontol, 11 : 193-207. 1983.

17) Nyman S, Rosling B, Lindhe J. Effect of professional tooth cleaning on healing after periodontal surgery. J Clin Periodontol, 2 : 80-86, 1975.

18) Nair P, Sutherland G, Palmer R M, Wilson R F, Scott D A. Gingival bleeding on probing increases after quitting smoking. J Clin Periodontol, 30 435-437, 2003.

19) Morozumi $T$, Kubota $T$, Sato $T$, Okuda K, Yoshie $\mathrm{H}$. Smoking cessation increases gingival blood flow and gingival crevicular fluid. J Clin Periodontol, 31 : 267-272,2004.

20) Badersten A, Nilveus R, Egelberg, J. Effect of nonsurgical periodontal therapy. VI. Localization of sites with probing attachment loss . J Clin Periodontol, 12:351-359, 1985.

21) Etter J F, Vu Duc T, Perneger T V. Saliva cotinine levels in smokers and nonsmokers. Am J Epidemiol, $151:$ 251-258, 2000.

22) Jette A M, Feldman H A, Douglass C. Oral disease and physical disability in community-dwelling older persons. J Am Geriatr Soc, 41 : 1102-1108, 1993. 